\title{
INTELLECTUAL CAPITAL, COMPETITIVE ADVANTAGE (EVIDENCE FROM INDONESIA'S MANUFACTURING SECTOR)
}

\author{
Peggy Delita Merida \\ Widya Mandala Surabaya Catholic University \\ peggy@ukwms.ac.id
}

\section{A R T I C L E I N F O \\ Article history: \\ Received : 2 March 2021 \\ Revised: 29 March 2021 \\ Accepted : 30 March 2021}

Keywords:

Intellectual capital; competitive

advantage

DOI:

https://doi.org/10.33508/rima.v4i1.3058

\begin{abstract}
A B S T R A C T
The study aims to examine the direct relationship between intellectual capital and competitive advantage. The contribution of this paper is that there is a proxy competitive advantage. The study was conducted on 444 manufacturing companies in Indonesia from 2013-2017. This study's novelty is a research model that makes competitive advantage a dependent variable for intellectual capital and competitive advantage variables using market share proxy. The result of this study is intellectual capital has a positive effect on competitive advantage.
\end{abstract}

\section{INTRODUCTION}

In the competitive era of business scope, capital intellectuals having a vital role in keeping competitive advantages. Literature about conceptualization and capital intellectual management start to accepted momentum from the last second decade.

This moment leads to more acknowledgment from the academic community and practical work to reach a competitive advantage for the company's knowledge (Segelod, 1998). Intellectual assets such as patents, trade secrets, human capital, and organizational structures are essential to business performance and economic growth.

Hopefully, capital intellectuals could give a competitive advantage to the company. "There has been a growing interest in resource-based capability as sources of profitability" (Collis \& Montgomery, 2008). Companies tend to have solid competitors and many ways do for business, such as: change the methods for doing business. The main characteristics of a company's basic knowledge could increase competitive advantage. Because there was a changing, means-based growth company is knowledge to established value creation, the focus shift from benefit individual asset becomes several groups of assets, half of which was an intangible asset. Companies' business activities aim to increase performance in every period, seen through market share (Agustia, 2012).

Intellectual assets such as patents, trade secrets, human capital, and organizational structures are widely considered significant contributors to business performance and economic growth. Intellectual capital is one of the organizational capabilities that positively impact competitive advantage (Amiri et al., 2010). Another benefit of reporting intellectual capital, communicate their position. The company could pull human capital for value-added in the company. Intellectual capital (IC) having a strong relationship with resource-based theory.

In resource-based opinion, explain about social capital company and how the company could develop a competitive 
advantage, the company should have human capital and superior ability more than competitors.

The company could manage and utilize the source of its intellectual capital effectively and efficiently to get the best benefit. Companies can increase their profit if they can get value-added by minimalizing cost. Human capital is one of the main factors for the knowledge industry because it is the dominant cost in the production process. So, if all employees quit the company, the company will not have any values.

The competitive advantage concept tells the success of sustainability business reach through competitive advantage. It should create a benefit to customers when they build a business strategy. That value in cost leadership will show product and service to customers with affordable prices, differentiation product, service aspect, or responsive aspect better toward the customer's need in a niche than competitors in the industry. Competitive advantage as a base to run the strategy can reach sustainability growth (Simpson, M., Taylor, N., \& Narker, K., 2004).

Chen (2008) says that intellectual capital has a positive impact on competitive advantage. Dyer and Singh (1998), the potential company, depends on the responsible capital company in context. Aun (2008) argue if intellectual capital on expert employee determines the result of competitive advantage. Besides, Barney (1991) tell the company with a combination ability human capital and optimize to get a sustainable advantage market and then reduce the cost and take the proactive measurement.

Opinion from the researcher, intellectual capital has a positive impact on competitive advantage. Higher intellectual capital leads to competitive advantage, cause these two variables to have a positive effect. New findings in this research were proxy from competitive advantage, has found from market share are net sales divided by total sales all of the company.

\section{LITERATURE REVIEW}

\section{Resource-Based View (RBV)}

Collis and Montgomery, "RBV were tools to know the success factors from the human capital organization able to support competitive advantage. Then the organization could develop a better strategy." Warnelfelt tells human capital is something considered as the strength and weakness of the company.

Human capital was a tangible and intangible asset that is bond semipermanent in the company, such as merk, knowledge in-house, technology, expert employees, trade contract, machine, efficiency procedure, and capital. Next, Rumelt (1984), Barney (1986, 1991), and Dierick Cool (1989) giving a contribution to developing RBV the next management strategy.

Wernerfelt (1984) tells RBV was based primary competitive advantage based on the association of tangible assets or intangible assets. RBV planed the company's ability to give a competitive sustainability advantage. Simultaneously, human capital management created a unique product that is difficult to copy by competitors ended up with build thread competition (Mahoney and Pandian, 1992).

This view is supported by Peteraf (1993), which stated to transform competitive advantage in a short time to become a competitive advantage, the human capital company should be heterogeneous and irreplaceable. RBV theory sees the company as an association between human capital and the strength of the company. RBV focuses on the company's power to keep the human capital combination, which could not create with competitors. 
The difference in resources and the company's ability with competitors will provide a competitive advantage. According to the company's capabilities, the RBV assumption is how a company can compete with other companies to gain a competitive advantage in managing its resources. The RBV theory states that sustainable competitive advantage rests on organizational resources that are extremely valuable, rare, inimitable, and nonconstitutable (VRIN).

Incorporate settings with policies and procedures to exploit resources (Barney, 1991; Barney \& Clark, 2007; Knott, 2003; Kraaijenbrink, Spender, \& Groen, 2010). According to some experts, the RBV explained the intangible assets and their ability to compete; therefore, this study used RBV (Resources Based View) as a grand theory.

\section{Competitive advantage}

Ma (2004) explains that "competitive advantage is a condition of positional superiority, which is organizational occupies where its successful strategies are difficult to be copied." It then helps the organization to get sustainable benefits. Ma (2004) suggests a competitive advantage due to valuable, rare, unsubstituted, and unique resources resulting from integrating resources and capabilities.

In this context, Iuliana et Al. (2008) state that the selection of activity or field plays a vital role in obtaining a sustainable position. Collis and Cynthia (1995) further develop this concept in terms of endurance, excellence, and suitability.

In general, the competitive advantage is categorized into three types: 1) cost leadership in delivering products and services at the lowest prices in the industry, 2) product and service differentiation, and 3) responsive to the needs of specific targeted segments. These factors will lead to an organization's success in building a competitive advantage, further developing business strategies to achieve sustainable growth and survival capabilities.

Since the creation of competitive advantage varies with the business environment, both in aspects of technology use or collaboration between organizations, each organization's ability to build a competitive advantage will differ.

Competitive advantage can be achieved in two different ways: creating cost leadership and creating differentiation (Porter, 1985). Firms that are low-cost in the market may not create better performance. Instead, if a firm has a competitive advantage either from differentiation or cost, it may create and increase its better performance (Ma, 2000).

According to the RBV, if a firm has valuable, inimitable, and rare resources, it can ensure its performance through competitive advantage (Barney, 1991), and the effectiveness of dynamic capabilities leads firms to achieve competitiveness. Hence, superior performance is required in the new production processes and practices of a new business model.

The development of dynamic capabilities is defined as the firm's fast reconfiguration in a turbulent environment. In this research, competitive advantage is sales leadership to its competitors, showing the competitiveness of a company.

\section{Intellectual Capital}

According to PSAK No. 19 revised 2000 (Indonesian Institute of Accountants, 2012) concerning intangible assets. Intangible assets or intangible assets are defined as follows: "Intangible assets or intangible assets are non-monetary assets that can be identified and do not have the physical form."

Intellectual capital or intellectual capital is one of the resources owned by the company. Stewart defines intellectual 
capital in his article: "intellectual capital in the form of intellectual knowledge, information, intellectual property rights, an experience that can create wealth." Kartika and Hartono (2013: 17) concluded that: "Intellectual capital is the main asset of a company and physical and financial assets.

So in managing physical and financial assets, a reliable capability from intellectual capital itself is needed. Besides producing a valuable product, employees' ability and thinking power are required and manage the organization and establish relationships with external parties.

From some of the above, understanding concluded that the definition of intellectual capital or intellectual capital is an intangible asset indirectly mentioned in the financial statements, which can be in the form of information and knowledge resources that can increase the ability to compete in a company.

Intellectual Capital consists of several types of knowledge-based resources. A three-dimensional categorization of IC human-, organization- and relationshipcentered- has been established as an emergent standard and a premise for building the measurement models. Human capital regards the firm's employees and their knowledge, education, skills, capabilities, and characteristics (Bontis, 1998; Dzinkowski, 2000; Edvinsson and Malone, 1997; Roos and Roos, 1997; Stewart, 1997).

Organisation-centered (e.g., organizational and structural) capital includes the knowledge embedded in information technology (IT) systems and the outcomes and products of knowledge conversions, such as documents, databases, process descriptions, plans, the intellectual properties of the firm, and all the nonhuman storehouses of knowledge within a firm (Bontis, 1998; Edvinsson and Malone, 1997; Stewart, 1997).

Finally, relationship-centred (e.g., relational and customer) capital consists of the value and knowledge embedded in the firm's external relationships, such as its connections with its customers, suppliers, distributors, partners, the local community, and all the related parties (Dzinkowski, 2000; Edvinsson and Malone, 1997; Roos and Roos, 1997). As the discussion mentioned above shows, the threedimensional categorization of IC was the primary approach described by the pioneering scholars.

Organizational analyses based solely on accounting systems have become insufficient to assess assets' intangible value (Nawaz \& Haniffa, 2017). IC has become an essential tool for companies' economic value creation (Jordão \& Almeida, 2017). IC is the addition of everyone's knowledge in the company, which provides a competitive advantage and forms intellectual matterknowledge, information, intellectual property. This experience can generate wealth and represent its knowledge, whose potential can be made into tangible profit (Nawaz \& Haniffa, 2017).

IC is the intangible asset represented by knowledge, brands, patents, and trademarks (Agostini et al., 2017). IC may be considered a value unseen in financial displays, whose value may be evaluated in the difference between steady Market value and accounting value (Clarke, Seng \& Whiting, 2011). IC includes a set of hidden values of capital, assets, or resources that add real value to an organization, thus allowing its continuity and better organizational performance.

Recurrent categorization in literature centers on human capital, structural/organizational capital, and client/social/ relational. Capital Human capital is a combination of knowledge, skills, experience, and the individual inherent capabilities. It concerns knowledge, capabilities, educations, skills, and characteristics.

Structural capital refers to what is owned by the company, and client capital 
consists of relationships with partners such as clients and suppliers as well as any other

In the new economy, intellectual capital is a significant resource in order to generate wealth and growth. It is also a potent company performance enhancer and a market value booster (Wang \& Chang, 2005; Tseng et al., 2013). Through relational resource, namely reputation, brand, and loyalty (Agostini et al., 2017).

knowledge management, experience, intellectual property, and information, IC may be used to create wealth, thus becoming vital for organizational performance (Amin \& Aslam, 2017).

\section{Research Framework}

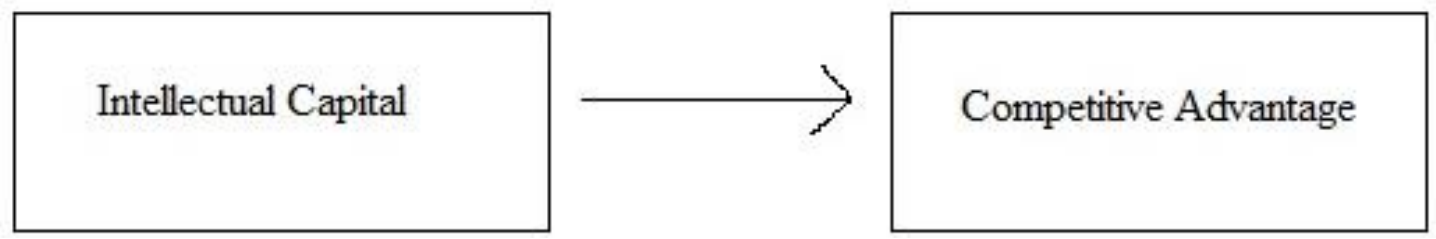

Figure 1. Research Framework

\section{Hypotheses}

The Relationship Between Intellectual Capital and Competitive Advantage.

Chen (2008) says that intellectual capital has a positive influence on competitive advantage. In this context, Dyer and Singh (1998) cite that a company's potential to create a competitive edge depends on the company's Intellectual Capital.

Aun (2008) argues that Intellectual Capital in skilled employees determines the results of competitive advantage. Also, Barney (1991) explains that companies with a combination of valuable and optimal resource capabilities can obtain sustainable profits in the market, enabling them to reduce costs and take proactive measurements.

According to researchers, Intellectual capital has a positive influence on
Competitive advantage. With a high Intellectual Capital, the company's competitiveness is also higher; therefore, two variables can positively affect it.

H1: Intellectual Capital has a positive effect on competitive advantage.

\section{RESEARCH METHOD \\ Definition of Variable Operations}

Intellectual Capital

The first variable is Intellectual Capital. Intellectual capital is an intangible asset indirectly mentioned in the financial statements, which can be in the form of information and knowledge resources that can improve competitiveness and improve company performance - in this study, measuring Intellectual Capital by using the formula.

Intellectual Capital $($ IC $)=\frac{\text { Intangible Assets }+ \text { Goodwill }+(\text { enterprise value }- \text { book value })}{\text { Enterprise value }}$

Notes:

Enterprise $=$ Market share price $x$ shared issued and outstanding + Net Debt

Book value $=$ Shareholder's equity + Net Debt

Source: Mc Guire \& Brenner (2015) 
Competitive Advantage

Competitive advantage refers to companies' ability to create defensive positions against their competitors' positions (Porter, 1985). Measurement of competitive advantage using the company's market share.

These proxies were developed by researchers following the definition of competitive advantage from various experts, namely the ability of a company to compete with other companies, competition with other companies, which could compare net sales results with all companies' total sales.

The higher the company's ratio, the better its competitiveness. The formula used is the market share formula:

$$
\text { Market Share }=\frac{\text { Nett Sales }}{\text { Total Sales }}
$$

Source:Processed by researchers for the competitive advantage formula

\section{Return On Assets (ROA)}

$\mathrm{ROA}$ is an indicator of a business unit's ability to obtain a return on several

\section{Population and Sample}

The sample used was 444 manufacturing companies in Indonesia in 2013-2017.

\section{Method of collecting data}

Data done through documentation studies. Through this documentation method, data collection procedures are used to obtain data on financial statements for Manufacturing companies listed on the IDX. assets owned by the business unit. Return On Assets measures operating performance, which shows the extent to which assets are carried out.

This ratio measures how effective the company is in utilizing existing economic resources to generate profits.

The ROA formula could calculate as follows:

$$
\text { Return On Assets }=\frac{\text { Net Income }}{\text { Total Asset }}
$$

Source: Bayraktaroglu et al. (2019)

\section{Company Size (Size)}

Company size can calculate using a company's total assets. The formula for company size is as follows:

$$
\begin{gathered}
\text { Size }=\text { Ln Total Assets } \\
\text { Source: Nimtrakoon (2015) }
\end{gathered}
$$

\section{$\underline{\text { Research Model }}$}

Based on the independent variables and the dependent variables above, we can use the following equation:

$$
\text { Cait }=£ 1+\beta 2 \text { Icit }+X 1+X 2+\text { e1it }
$$

\section{Technical Data Analysis}

Data analysis performed was quantitative analysis expressed by numbers and calculations using STATA 13.

\section{Empirical Results}

Stata is used in research to test hypotheses. Before examining the theory, it is necessary to do descriptive statistics for the data first.

Here is a statistics table.

Table 1 Descriptive Statistics

\begin{tabular}{|l|l|l|l|l|l|}
\hline Var & Obs & Mean & Standard Dev & Min & Max \\
\hline Ic & 444 & .0183932 & .9480628 & -7.8868 & 2.4871 \\
\hline Size & 444 & 28.31437 & 1.572634 & 24.4142 & 33.3202 \\
\hline Roa & 444 & .0576338 & .087318 & -.1611 & .6572 \\
\hline Ca & 444 & 1.083108 & .7245123 & .02 & 8.43 \\
\hline
\end{tabular}


Based on the data table above shows that the mean of the intellectual capital variable is 0.0183932 . Intellectual capital is obtained from intangible assets, goodwill, enterprise value, book value in manufacturing companies.

The dependent variable competitive advantage refers to the company's sales on all manufacturing companies' total sales has a mean of 1.083108. Size and Roa as control variables have a way of 28.31437 and 0.0576338 .

\section{Hypothesis Test}

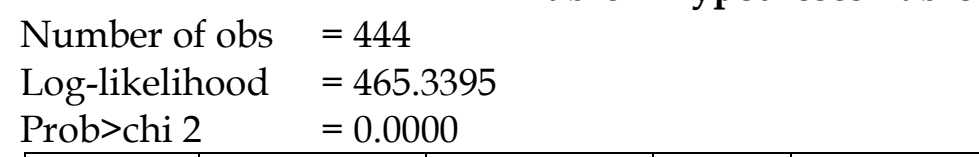

\section{Table 2 Hypotheses Table}

\begin{tabular}{|l|l|l|l|l|l|l|}
\hline Ca & Coef & Std.Err & $\mathrm{z}$ & $\mathrm{P}>[\mathrm{z}]$ & $95 \%$ conf & Interval \\
\hline Ic & .0770886 & .0379568 & 2.03 & $0.004^{* *}$ & .0026946 & .1514826 \\
\hline Size & -.0865965 & .0219723 & -3.94 & 0.000 & -.1296615 & -.0435315 \\
\hline Roa & 1.994453 & .4009545 & 4.97 & 0.000 & 1.208597 & 2.780309 \\
\hline _Cons & 3.418668 & .06208078 & 5.51 & 0.000 & 2.201907 & 4.635429 \\
\hline
\end{tabular}

Notes:

Total data $=444$

*** Signification level 1\%.

** Signification level $5 \%$.

* Signification level 10\%.

\section{RESULT AND DISCUSSION}

The results of hypothesis testing in Table 2 show that for H1, Intellectual Capital has a positive influence on competitive advantage. This can be seen from the P-value of 0.000 or significant impact at the $5 \%$ level. This test is a Fix effect, in line with Zeglat and Zigan's (2014) research, explaining that intellectual capital has a significant positive impact on competitive advantage.

This study states that the hypothesis is accepted, saying that Intellectual Capital has a positive effect on competitive advantage shows that a company's intangible assets influence the competitive edge because it requires a high intellectual property to achieve a competitive advantage against other companies.

The company could utilize and manage the source of its intellectual capital effectively and efficiently to get the best profit. The company can increase profit if they can get value-added with a minimalizing cost. Human capital is one of the main factors for the knowledge industry because it is the dominant cost of in-process production.

So, if all employees quit from the company will end up, the company did not have value. The competitive advantage concept tells the success of sustainability business reach through competitive advantage.

It should create a benefit to customers when they build a business strategy. That value in cost leadership will show product and service to customers with affordable prices, differentiation product, service aspect, or responsive aspect better toward the customer's need in a niche than competitors in the industry.

The study conceptualizes the framework of intellectual capital and 
considers competitive advantage. The managers can use intellectual capital as a tool to evaluate organizational performance, which enables them to know how intellectual capital can be created with the help of trained, educated, and creative employees.

Further, relational capital, one of the components of intellectual capital, can help managers understand, develop, and enhance employees' and customers' interactive and collaborative abilities.

The study also provides insights to the organizations in encouraging innovation ability among employees through positive culture and information technology, thus paving the way for building structural capital. Hence, it provides managers with a better understanding of how intellectual capital develops and drives performance.

The role of learning and innovation at different organization levels can be a significant indicator for developing and creating intellectual capital, which ultimately affects intellectual capital and competitive advantage.

Further, to encourage a greater understanding of the concept, the managers need to understand the nature of competitive advantage in enhancing and improving the relationship between intellectual capital and business performance.

\section{CONCLUSION}

This study has a novelty that is a proxy of competitive advantage using market share from net sales divided by all companies' total sales. This study states, there is a relationship between Intellectual Capital with a competitive advantage.

The conceptual framework suggests a wide range of research implications as well. The proposed framework and propositions provide direction for research on a topic that is incredibly rich and invites its application to understanding its impact on different variables better.
The study would act as a stimulus for future research. It also lays the foundation for scholars in grounding the concept of intellectual capital and empirical testing of the framework in different settings with different relationships and variables. It enables the scholars, practitioners, academicians, management, and stakeholders to have a clear understanding of intellectual capital and provide richer insights into developing and creating intellectual capital.

\section{REFERENCE}

Abeysekara, N., Wang, H., \& Kuruppuarachchi, D. (2019). Effect of supply-chain resilience on firm performance and keunggulan kompetitif: A study of the Sri Lankan apparel industry. Business Process Management Journal, 25(7), 1673-1695. https://doi.org/10.1108/BPMJ-092018-0241

Antoncic, B., Prodan, I., Hisrich, R.D., Scarlat, C. (2007), “Technological innovativeness and firm performance in Slovenia and Romania", PostCommunist Economies, Vol. 19, No 3, pp.281-292.

Ambrosini, V., Bowman, C. (2009), "What are dynamic capabilities and are they a useful construct in strategic management," International Journal of Management Reviews, Vol. 11, No 1, pp.29-49.

Astuti, P. D., Chariri, A., \& Rohman, A. (2019). Association between intellectual capital and keunggulan kompetitif: A case study on the hotel industry in Bali province, Indonesia. Humanities and Social Sciences Reviews, 7(4), 440-449. https://doi.org/10.18510/hssr.2019.74 $\underline{60}$

Barney, J. B., \& Hesterly, W. S. (2010). VRIO framework. Strategic management and keunggulan kompetitif, 68-86. 
Bharadwaj, A. S. (2000). A resource-based perspective on information technology capability and firm performance: an empirical investigation. MIS Quarterly, 169-196.

Barreto, I. (2010), "Dynamic capabilities: A review of past research and an agenda for the future," Journal of Management, Vol. 36, No 1, pp.256-280.

Birchall, D., Tovstiga, G. (2005), Capabilities for strategic advantage: Leading through technological innovation, Basingstoke, Palgrave Macmillan.

Burgelman, R., Maidique, M.A., Wheelwright, S.C. (2004), Strategic management of technology and innovation, New York, McGraw Hill.

Camisón, C., \& Villar-López, A. (2014), "Organizational innovation as an enabler of technological innovation capabilities and firm performance," Journal of Business Research, Vol. 67, No 1, pp.2891-2902.

Cepeda, G., Vera, D. (2007), "Dynamic capabilities and operational capabilities: A knowledge management perspective," Journal of Business Research, Vol.60, No 5, pp.426437.

Chen, J., Zhu, Z., \& Xie, H. Y. (2004). Measuring intellectual capital: a new model and empirical study. Journal of Intellectual Capital, 5(1), 195-212. https://doi.org/10.1108/14691930410 513003

Cho, H.J., Pucik, V. (2005), "Relationship between innovativeness, quality, growth, profitability, and market value," Strategic Management Journal, Vol. 26, No 6, pp.555-575.
Danneels, E. (2008), "Organizational antecedents of second-order competences," Strategic Management Journal, Vol. 29, No 5, pp.519-543.

Edvinsson, L., \& Malone, M. S. (1997). Intellectual capital: realizing your firm's true value by finding its hidden brainpower. New York: Harper Collins.

Ghozali, Imam. 2016. Aplikasi Analisis Multivariete Dengan Program IBM SPSS 23 (Edisi 8). Cetakan ke VIII. Semarang : Badan Penerbit Universitas Diponegoro.

Jansze, W., Lahiri, D., \& Tuninga, R. S. J. (2008). Gaining keunggulan kompetitif by technological innovation in emerging countries: Nature or nurture for Suriname? Journal of Transnational Management, 13(3), 226-243. https://doi.org/10.1080/15475770802 $\underline{402554}$

Lahovnik, M., \& Breznik, L. (2014). Technological innovation capabilities as a source of keunggulan kompetitif: A case study from the home appliance industry. Transformations in Business and Economics, 13(2), 144-160.

Potjanajaruwit, P. (2018). Keunggulan kompetitif effects on firm performance: a case study of startups in Thailand. Journal of International Studies, 11(3), 104-111. https://doi.org/10.14254/20718330.2018/11-3/9

Suseno, N. S., Hermina, T., Ramdhani, A., \& Utari, L. (2019). The impact of intellectual capital on financial performance. International Journal of Recent Technology and Engineering, 8(1), 359-365.

https://doi.org/10.30871/jama.v1i1.1 239 
Gasperz, V., Fontana, A., 2011. A Lean Six Sigma for Manufacturing and Service Industries. Vinchristo Publication, Bogor.
Xu, J., Shang, Y., Yu, W., \& Liu, F. (2019). Intellectual capital, technological innovation, and firm performance: Evidence from China's manufacturing. 